Article

\title{
Seeing and Hearing in the Laozi and Zhuangzi and the Question of Authority and Authenticity
}

\author{
Andrej Fech \\ Department of Chinese Language and Literature, Hong Kong Baptist University, Kowloon Tong, \\ 22100 Kowloon, Hong Kong, China; anfech@hkbu.edu.hk
}

Received: 5 January 2019; Accepted: 27 February 2019; Published: 4 March 2019

check for updates

\begin{abstract}
The present paper investigates the significance of visual and auditory metaphors as used in the main Daoist classics the Laozi 老子 and Zhuangzi 莊子. While both works disparage the role of the senses, they nonetheless employ a large number of metaphors related to the sense experience. It is the contention of the author that examining these metaphors against the backdrop of the main modern theories dealing with characteristics of vision and hearing is crucial for a better understanding of how the authors of both works envisioned the ideal relation between man and the Way (dao 道) as well as their views on authority and authenticity.
\end{abstract}

Keywords: seeing; hearing; grasping; heedfulness; authenticity; authority; Laozi; Zhuangzi

\section{Introduction}

This paper discusses the auditory and visual metaphors for human cognition as employed in the main Daoist classics the Laozi 老子 and Zhuangzi 莊子 and explores their possible relation to the topics of authenticity and authority.

It is a well-known fact that, in many central Daoist works, the senses are often identified as the main obstacle for realization of the ineffable reality that is called in these works, the Way (dao 道). Having the potential for creating distractions and fuelling desires, sensory perception has to be reduced to the lowest possible limit, at least for some time, to facilitate the cognition of the Way that lies beyond the sensual world. Thus, the "gate is to be closed" (bi qi men 閉其門) to employ a line from Laozi 52 and $56^{1}$ and “limbs and perceptiveness are to be discarded" (duo zhi ti chu cong ming 墮肢體, 黜聰明) to reach the state of utter "forgetting" (wang 忘) as Yan Hui 顔回 claims in the Zhuangzi (6/19/21) 2 . And yet, in the same works, there are passages depicting the ultimate apprehension of that highest reality, or, at least, crucial stages leading up to it, by means of visual and auditory metaphors. To mention the Zhuangzi again, the protagonist "Ziqi of Southwall" (Nanguo Ziqi 南郭子綦) talks about his spiritual realization as having acquired the ability to "hear" (wen 聞) the "pipes of Heaven" (tian lai 天籟) (2/3/17), whereas another fanciful character "Woman Crookback" (Nü Yu 女偶) explains the importance of achieving the "brightness of the dawn" (zhao zhe 朝徹) allowing one to "see aloneness" (jian $d u$ 見獨) as a crucial stage in achieving “completion” (cheng 成) $(6 / 17 / 14)$.

The reason for this seeming contradiction may lay in the complex nature of the highest Daoist spiritual realization which, generally, "conquers, absorbs and finally employs sensory experience"

1 Interpreting this line in Laozi 52, Wang Bi writes (Wagner 2003, pp. 295-97): 兑，事欲之所由生；門，事欲之所由從 也。“'Openings' are the basis from which desires for action arise. 'Doors' are the basis on which desires for action are pursued."

2 Chapter/page/line references used in the paper when quoting the Zhuangzi and, in some cases, Laozi are from the concordance editions of these works published by Chinese University of Hong Kong (Cheuk and Ching 1996, Cheuk et al. 2000). 
(Kohn 1998, p. 14033). But it can also simply stem from the fact that sensual (and, especially, visual) metaphors are among the most indispensable linguistic tools for describing human cognition (Lakoff and Johnson 1999, pp. 238-39). Thus, even when generally disparaging the role of the senses, Daoist authors simply could not avoid using metaphors related to sense perception when describing the realization of their highest principles. Be that as it may, as metaphors for cognition, vision and hearing have very different connotations. As noted by Hans Blumenberg, seeing, in addition to other important characteristics ${ }^{4}$, implies the relative independence of the perceiving subject, whereas hearing often connotes passivity and obeisance. In most cases, this difference can be plausibly explained by referring to the physiological characteristics of the respective organs of perception, because, so Blumenberg argues, "the eye wanders, selects, approaches things, presses after them, while the ear, for its part, is affected and accosted. The eye can seek, the ear can only wait. Seeing 'places' things; hearing is placed" (Blumenberg 1993, p. 48). Moreover, hearing is also significant for understanding the "phenomenon of tradition" (Idem). It is this connection to tradition that Hans-Georg Gadamer regards as the main characteristic of hearing (and language in general). ${ }^{5}$ Later, these findings were supported and formulated even more incisively by linguist Eve Sweetser, who, in her study involving Indo-European languages, determined "the ability to pick out one stimulus at will from many" as "a salient characteristic of vision and of thought" and "evidence of control" (Sweetser 1990, p. 38) and also established a close connection between hearing and "linguistic communication" as well as "heedfulness" (Sweetser 1990, pp. 41-43).

The analysis of the respective role of the senses in Chinese philosophy has been practically developing along similar lines. ${ }^{7}$ In regard to the Daoist classics, however, not much work has been done. Some scholars even claim that "in the Laozi and the Zhuangzi, it is not the relative importance of seeing or hearing that demands attention, but rather the threat to innocence, authenticity and freedom" (Chan 2014, p. 115). However, I argue that the investigation of the "relative importance of seeing or hearing" in central Daoist classics can shed light on how their authors envisioned the role of the cognizing subject and his ideal relation to the main principles those texts promulgated. In the present study, the main characteristics of the two senses will be formulated as follows: "seeing" presupposes a relative freedom of the subject as well as a certain "control" / "authority" over the objects so perceived, whereas "hearing" signifies the subjects' heedfulness, indebtedness to tradition and submission to "authority". That is, I understand "authority" simply in terms of the ability to exercise control and influence. "Authenticity", on the other hand, is to be treated as the main precondition for any claims to truth (and power).

I focus on the main verbs denoting vision and hearing in Classical Chinese, such as "to see" (jian 見), “to look at" (shi 視), “to observe" (guan 觀), “to listen to” (ting 聽) and “to hear" (wen 聞). Moreover, I investigate such notions as “light” (guang 光), “clear-sightedness/illumination" (ming 明), "sharp hearing" (cong 聰) and so forth, as they connote conditions for effective use of the respective

3 When contrasted with Daoist teaching, other intellectual traditions promulgate differing subjects of cognition as well as a less complex process leading to the respective highest realization. For more, see Brown and Bergeton (2008, p. 657).

4 Blumenberg distinguished between the vision-oriented intellectual tradition of the ancient Greek and the religious faith (of the Bible) with its predominant metaphor of "hearing" (Blumenberg 1993, p. 46): "For the Greeks, 'hearing' is of no significance for truth and is initially nonbinding. As an imparting of doxa, it represents an assertion that must always be confirmed visually. For the Old Testament literature, however, and for the consciousness of truth it documents, seeing is always predetermined, put into question, or surpassed by hearing. The created is based on the Word, and in terms of its binding claim, the Word always precedes the created."

5 Gadamer writes (Gadamer [1960] 1998, p. 478): "in contrast to all other experience of the world, language opens up a completely new dimension, the profound dimension from which tradition comes down to those now living."

6 Moreover, the "gaze" as an instrument of objectification and control has become a prominent topic in last century's philosophy (Sharma and Barua 2017).

7 Some scholars, explicitly following Gadamer, interpret the role of "hearing" in Confucian classics as an active dialogue with tradition, leaving room "for innovation and individual flourishing" (Chan 2014, pp. 114-15). Others, however, emphasize sound's "penetration" through the ears in the process of hearing which suggests "inescapable obedience" (Geaney 2011, p. 134). 
senses. Finally, to prove the validity of my working hypothesis in regard to the role of the senses, I also consider notions implying control and authority, on the one hand, such as "grasping" (zhi 執), “embracing" (bao 抱), “obtaining" (de 得), and, on the other hand, concepts signalling submission to "authority", such as "following" (cong 從; yin 因) and "modelling oneself on" (fa 法). The term I choose for "authenticity" is zhen 真. 8

\section{The Laozi}

\subsection{Visual Metaphors}

Although the Laozi depicts the Way as a formless entity undetectable for the senses, it is, strictly speaking, not devoid of any sensual qualities. It is especially true in regard to its utter "darkness" that is among the most frequent attributes the text imparts on the Way using a number of related notions. The most frequent of them is certainly xuan 玄 appearing in the text twelve times. ${ }^{9}$ But others, like “dim" (you 窈; ming 冥), also play an important role. Laozi 21 says, for instance:

\section{恍兮忽兮，其中有物。窈兮冥兮，其中有精 ; 其精甚真，其中有信。}

Shadowy and indistinct,

Yet within it is a substance.

Dim and dark,

Yet within it is an essence.

This essence is quite genuine

And within it is something that can be tested. (Lau 2001, pp. 32-33)

Accordingly, the Way is not only "indistinct", but, at the same time, also "dim" and "dark". However, inside of its "dimness" there is a genuine and reliable "essence" (jing 精). While giving here no explanation as to how this dark essence can be recognized, the Laozi still employs a number of visual metaphors when talking about the realization of its highest truths. These metaphors seem to be distinct from the ordinary use of vision ( $s h i$ 視) whose role is consistently rejected (chapters 14 and 35). The most significant among them is "clear-sightedness; illumination or enlightenment" (ming 明) appearing in the text twelve times. ${ }^{10}$ Laozi 52 is particularly dense in regard to visual metaphors as well as the related imagery of light:

\section{見小曰明，守柔日强。用其光，復歸其明，無遺身殊；是為習常。}

(Laozi 52A/18/5)

Seeing what is small is called enlightenment. Keeping to weakness is called strength. Use the light. Revert to enlightenment. And thereby avoid danger to one's life-This is called practicing the eternal. (Chan 1963, p. 164)

The opening definition of this passage was interpreted very differently by the two most influential commentators of the Laozi, Wang Bi 王弼 (226-249) and (legendary) Heshang Gong 河上公. While the former reads the first two characters as "manifesting smallness" (xian xiao 見小), that is, assuming humble public appearance (as a ruler) ${ }^{11}$, Heshang Gong interprets them as "seeing the small",

8 The term cheng 誠, used to signify "true and genuine without falseness" as the basis of all other cardinal virtues in such Confucian works as the Zhongyong 中庸 (Johnston and Wang 2012, p. 209), plays no role in the two Daoist texts selected for this study.

9 Chps. 1, 6, 10, 15, 51, 56 and 65.

10 Chps. 10, 16, 22, 24, 27, 33, 36, 41, 52, 55 and 65. A related metaphor is "white" (bai 白) appearing in chps. 10, 28 and 41.

11 Wagner (2003, p. 297): 為治之功不在大, 見大不明, 見小乃明。“[A ruler's] achievements of acting and ordering do not consist in [acting] great. Showing off being great is not being enlightened, 'to manifest smallness is,' in fact, 'being enlightened'." 
highlighting the sage's unique visual abilities, that is, cognition. ${ }^{12}$ The latter view has become the standard interpretation of the passage. And even though in this particular example, Heshang Gong understands the object of sagely cognition, the "small" (xiao 小), as the time when "misfortune and disorder are not yet manifest" (huo luan wei xian 禍亂未見), “smallness" is one of the main attributes of the Way in other chapters (most prominently, in Laozi 32) ${ }^{13}$, so that interpreting the "small" as the Way would certainly be in line with the text's standpoint.

The central part of the passage: yong qi guang fu gui qi ming 用其光, 復歸其明, has been likewise subject to radically different interpretations. ${ }^{14}$ Wang Bi interprets "light" (guang 光) positively as the ability of the sage to "make shine forth the Way" (xian dao 顯道), while rejecting ming as the "negative form of a false behaviour of the ruler" (Wagner 2003, p. 480) ${ }^{15}$, thus deviating from his positive reading of the same term appearing in the opening line. Heshang Gong, on the other hand, takes these two sentences to address the outer ${ }^{16}$ and inner ${ }^{17}$ applications of sagacious vision. ${ }^{18}$ The latter case is designated by Heshang Gong as "inward vision" (nei shi 内視) and is used on two more occasions in his commentary. ${ }^{19}$

Despite these stark differences, it is clear from the above that, even in Wang Bi's interpretation, the sage was viewed as the source of "light" (guang 光) allowing him to see things clearly. However, Laozi 58 reminds the sage that his "light" should not be "dazzling" (yao 燿):

\section{是以聖人方而不割, 廉而不齪, 直而不肆, 光而不燿。}

Therefore the sage is square-edged but does not scrape,

Has corners but does not jab,

Extends himself but not at the expense of others,

Shines but does not dazzle. (Lau 2001, p. 85)

Although the subject of the sentence, the "sage" (sheng ren 聖人), is absent from the earliest excavated versions of the text (Gao 1996, p. 112), it is clear from context that these lines depict an ideal form of behaviour. "To shine but not dazzle" means, in Heshang Gong's interpretation, that the sage, although having unique cognitive abilities, makes his outer appearance "obscure" (anmei 闇昧) so as "to not bedazzle people with his brightness" (不以曜亂人) ${ }^{20}$. This is consistent with the depiction of the sage

12 Laozi 52.11C/115/15: 昭然獨見為明。“To see something alone in an illuminating manner is clear-sightedness.”

13 Heshang Gong commentary of the first line of chapter 32 reads, for instance (Laozi 32.2C/83/17): 道樸雖小，微妙無形，天 下不敢有臣使道者也。“Although the simple Tao is small, it is subtle and without form. There is no minister in the world who dares to use the Way" (Chan 1991, p. 136).

14 Among the most popular translations of the text, the interpretations vary as far as: "He who having used the outer-light can return to the innerlight" (Waley [1934] 1994, p. 206); "If you use the rays to return to the bright light" (Henricks 2000, p. 21), "Use the light but give up the discernment" (Lau 2001, pp. 75-77).

15 Wang Bi's comment on the line fu gui qi ming 用其光, 復歸其明 is (Wagner 2003, pp. 296-97): 不明察也。“[That is, if he] does not use [his] intelligence to spy [on other entities]."

16 Laozi 52.13C/115/23: 用其目光於外, 視時世之利害。“This means to use one's vision externally to see the good and bad fortune of the present situation" (Chan 1991, p. 147).

17 Laozi 52.13C/115/27: 復當返其光明於内, 無使精神泄也。“[T] allow the essence and spirit to be discharged" (Chan 1991, p. 147).

18 Some scholars believe that the terms ming 明 and guang 光 as employed in the Laozi connote two different kinds of wisdom, the "inner" and the “outer" respectively. See Gao Ming (Gao 1996, p. 78), who attributes this view to Zhu Qianzhi 朱謙之.

19 Laozi 15 (15.3C/51/5) and 33 (33.2C/84/31). For translation, see Erkes (1945, pp. 151, 182). In the subsequent centuries, “inward vision", together with the concomitant "reverse hearing" (fan ting 反聽), was to become an important meditative practice of Daoist practitioners. However, as opposed to Heshang Gong's view, where the outer and inner visions could coexist, the idea in later times was that to successfully master the practice of "inward vision" (which by then was believed to lead to the observation of one's inner organs) an adept had to first achieve "isolation from the outside world" (Chan 2010, p. 169).

20 Laozi 15.15C/128/1-2. Lo Yuet Keung even believes that the sage would forfeit his luminosity in exposing his light (Lo 1999, p. 154): "it is obvious that the sage can only preserve his ming by not revealing it. The fact that a person would reveal his ming (light) indicates that his mind is not ming (luminous) anymore." 
in Laozi 70 as someone who "while clad in homespun, conceals on his person a priceless piece of jade" (聖人被褐懷玉) (Lau 2001, p. 102). ${ }^{21}$

So, we see that, in Laozi's understanding, the sage appears as someone possessing not just the vision of unique strength and depth but also a certain control and regulating power over the intensity and direction of his luminosity. ${ }^{22}$ Such a person uses the light of his intellect to gain a clear sight of the mysteries of the "dark" Way (most likely to be understood as an inner process), while at the same time preventing it from shining too brightly on the outside to avoid confusion among the people. It is noteworthy that, while the former process has obvious epistemological connotations, the latter is rather to be understood in ethical terms.

\subsection{Auditory Metaphors}

As opposed to the numerous visual metaphors, passages involving auditory perception are rather rare in the Laozi. Just like “looking” (shi 視), “listening” (ting 聽) is said to be inept for providing us access to the mysteries of the Way in chapters 14 and 35. However, Laozi 41 employs the metaphor of "hearing" (wen 聞) in a way which suggests that it is indeed possible to gain (at least, some) cognition of the Way using auditory perception:

\section{上士聞道，勤而行之； 中士聞道，若存若亡；下士聞道，大笑之。不笑不足以為道。}

When the best student hears about the Way he practices it assiduously; When the average student hears about the Way it seems to him one moment there and gone the next; When the worst student hears about the way he laughs out loud. If he did not laugh it would be unworthy of being the way. (Lau 2001, p. 61)

In contrast to "listening", "hearing" does not always involve a direct experience of the matter so perceived as it can also mean "to hear about" something. This is the meaning in which this verb figures in the above passage, talking about instruction on the principles of the Way which, depending on the students' abilities, may or may not lead to their comprehension. Alan Chan has pointed out that the verb "hearing" as employed in Confucian classics often involves more than just auditory perception, referring to "asking questions, thinking, evaluating, and in short, the proves of learning and knowing through dialogue and critical engagement" (Chan 2014, p. 110). How much of it is true in regard to the Laozi is unclear but it certainly would not be an exaggeration to say that by introducing the topic of "hearing" the text acknowledges the importance of instruction. In light of this, it stands to reason that, although famously rejecting the conventional/Confucian curriculum for self-cultivation, the Laozi still suggested its own program which, ideally, could lead to the realization of the Way. This shows that the direct experience and comprehension of the Way vigorously championed by the text is embedded in the greater context in which a student initially has to accept and follow certain prescripts reflecting the authoritative experiences of others. Laozi 50 gives a good example of how "hearing" can refer to such authoritative knowledge formulated by others:

\section{蓋聞善攝生者, 陸行不遇兄虎, 入軍不被甲兵; 岇無所投其角, 虎無所措其爪, 兵無所容其 刃。}

I have heard it said that one who excels in safeguarding his own life does not meet with rhinoceros or tigers when travelling on land nor is he touched by weapons when charging into an army. (Lau 2001, p. 73)

21 The obscurity of a sage when compared to ordinary people is addressed especially in Laozi 20 (Lau 2001, p. 31): 沌沌兮, 俗 人昭昭, 我獨若昏。俗人察察, 我獨悶悶。“Vulgar people are clear. I alone am drowsy. Vulgar people are alert. I alone am muddled."

22 Some passages of the Laozi, just like its opening chapter, suggest that desire ( $y u$ 欲) has detrimental influence on one's “observing" (guan 觀), a person's cognitive abilities. 
The author of the Laozi clearly valorises this statement reflecting someone else's insight and accepts its authority.

\section{3. "Grasping" and "Following" Metaphors}

Sweetser contends that, just like with grasping and manipulation, "our visual picking out and monitoring of stimuli is evidence of control" (Sweetser 1990, p. 38). Given the frequent use of visual metaphors in the Laozi, it does not seem to be a coincidence that we find a large number of passages promulgating different kinds of control of the Way (or notions associated with it), such as "grasping" (zhi 執) (chapters 14 and 35), “embracing” (bao 抱) (chps. 10, 19 and 22), “securing” (shou 守) (chps. 32, 37 and 52), “obtaining" (de 得) (chps. 39 and 52). ${ }^{23}$ However, at the same time, other passages maintain that the Way (or associated values) cannot and should not become the object of any "grasping" (chps. 14, 29 and 64). I take this discrepancy to signal the rejection of conventional teachings and promulgation of new approaches to the Way.

To give examples of "grasping", Laozi 14 says:

\section{執古之道,}

以御今之有。

Hold fast to the way of antiquity

In order to keep in control the realm of today. (Lau 2001, p. 21)

Although it might be argued that the "way of antiquity" ( $g u$ zhi dao 古之道) ${ }^{24}$ is distinct from the Way as the source of the universe and an entity which can be experienced, other chapters mention "grasping" in a context allowing such an interpretation, just like the opening lines from chapter 35:

\section{執大象,}

天下往。

Have in your hold the great image

And the empire will come to you. (Lau 2001, p. 53)

Heshang Gong interprets the "great image" (da xiang 大象) as the Way. ${ }^{25}$ In both cases then, "grasping" the Way leads to the effective management of political affairs. Given this, it is not surprising to also find passages praising the advantages of "using" (yong 用) the Way (chps. 4, 6, 35 and 45).

The Laozi also contains passages which characterize the ideal relation between the human and the Way in terms of compliance, expressing an attitude akin to the one conveyed by auditory metaphors. Accordingly, the man should "follow" (cong 從) and "model oneself on" ( $f a$ 法) the Way. However, we find this idea only in three chapters $(21,23 \text { and } 25)^{26}$, which coincides with the rare use of auditory metaphors.

23 The notions in question have different connotations which cannot be discussed here at length. To give just one example, Behunaik (2009) maintains that "holding to the one" (zhi yi 執一) is radically different from "embracing the one" (bao yi 抱 -). Accordingly, while the former implies the "logical" order, whose "constituents [are] recognized not in their particularity but for their ability to satisfy a pre-designated function in a precedent order", the latter represents "a deference toward particularity and a preference for unforced, spontaneous orders" (Behunaik 2009, p. 366).

24 Both Mawangdui versions of the Laozi read "the Way of the present" (jin zhi dao 今之道) instead of "the way of antiquity" (Gao 1996, p. 288). The emphasis on using new solutions to contemporary problems as propagated by the Mawangdui versions is rather uncharacteristic of the Laozi, which always places a great weight on the antiquity of the Way. However, the slightly later Beida-version already confirms the reading of textus receptus (Beida-Laozi 2012, 150n8).

25 Laozi 35.1C/87/12-13: 執, 守也。象, 道也。聖人守大道, 則天下萬民移心歸往之也。“'Hold fast to' means to secure. The image is the Way. When the sage secures the great Way, all the people in the world will be reformed and return to him" Chan (1991, p. 152). Wang Bi, on the other hand, interprets this term rather vaguely as "mother of heavenly images" (tianxiang zhi mu 天象之母). For more, see Wagner (2003, p. 232).

26 Laozi 21 says, for instance (Lau 2001, p. 31): 孔德之容, 唯道是從。“In his every movement a man of great virtue follows the way and the way only." Laozi 25 uses the term fa (Lau 2001, p. 39): 人法地, 地法天, 天法道, 道法自然。“Man models himself on earth, Earth on heaven, Heaven on the way, and the way on that which is naturally so." 


\subsection{Visual and Auditory Metaphors in the Context of the Laozi's Philosophy}

It follows from the above discussion that first-hand knowledge of the Way and its application, mainly expressed by means of visual and grasping metaphors, could be gained only by a person who has fully opened himself to pertinent instructions, provided orally and mostly expressed through auditory metaphors. That is, humans are both in active and passive positions in regard to the Way and visual and auditory metaphors reflect this double standing very fittingly. However, it also became clear that the Laozi places by far greater emphasis on the human control of the Way. This seems to contradict the main principle of the Daoist school, "naturalness" (ziran 自然), which implies human "compliance" with the natural development of things, regardless of whether we talk about the inner (Slingerland 2003, p. 29) or outer (Liu 1999, p. 212) dimensions of our lives. I believe, however, that the emphasis on human agency can be explained through the pre-eminently political nature of the Laozi, which uses the Way as the most reliable instrument for establishing political authority (Fech 2018b). That the text emphasizes the "genuine/authentic" (zhen 真) nature of the Way (chapter 21) and identifies it as the factor ensuring the "authenticity" of human virtue (de 德) (chapter 54) makes unmistakably clear its paradigmatic function.

\section{The Zhuangzi}

The next text to be discussed are the inner chapters of the Zhuangzi. Although fully aware of the recent challenges of their traditional attribution to philosopher Zhuang Zhou 莊周 (Klein 2010), I nonetheless confine my analysis to this part of the text. I do this partly due to space limitations and partly because the inner chapters still occupy a special position among the other parts of the Zhuangzi in terms of linguistic and philosophical characteristics (Liu 1988, pp. 3-30).

\subsection{Visual Metaphors}

Most visual metaphors in the inner chapters can be found in the second chapter "Discussion of Making All Things Equal" (Qiwulun 齊物論). While introducing the important concept of "shining" (zhao 照), not seen in the Laozi, this chapter mostly operates with the already familiar notions ming 明， guang 光, bai 白 and yao 耀. However, despite the similar vocabulary and while generally agreeing with the Laozi on the inadequacy of sense perception, including vision ${ }^{27}$, the Zhuangzi draws a very different picture, provided the notorious ambiguity of the involved terms allows us to outline its position correctly. ${ }^{28}$

I start with a passage somewhat reminiscent of Heshang Gong's notion of "inward vision". In the famous dialogue from the fourth chapter, “In the World of Men" (ren jian shi 人間世), Confucius gives the following instruction to his favourite disciple Yan Hui after the latter appeared to grasp the concept of "fasting of the heart" (xin zhai 心齋):

瞻彼関者, 虛室生白, 吉祥止止。... 夫徇耳目内通而外於心知, 鬼神將來舍, 而況人乎! (Zhuangzi 4/10/3-4)

Look into that closed room, the empty chamber where brightness is born! Fortune and blessing gather where there is stillness. [ ... ] Let your ears and eyes communicate with what is inside and put mind and knowledge on the outside. Then even gods and spirits will come to dwell, not to speak of men! (Watson [1968] 2013, p. 25)

27 Zhuangzi 6/17/1: 夫道 [ ... ] 可得而不可見。“As for the Way, you can get it but cannot see it."

28 For instance, the notion bao guang 葆光, apart from the more common understanding as "shaded" / "dimmed" light in the sense of "shining but not dazzling" mentioned in the discussion of Laozi 58 (Wang (1988, p. 77), Gao (1996, p. 78), Lo (1999, p. 166)), is also read as "the light that issues from the very split between light and darkness" (Møllgaard 2007, p. 141), "inner light" (Mair 1994, p. 20) and, even, "Benetnash Star" (Graham [1981] 2001, p. 57). Another controversial notion, hua yi zhi yao 滑疑之耀, has been interpreted variously as "torch of chaos and doubt" used by the sage (Watson [1968] 2013, p. 12), "glitter of glib implausibilities" despised by the sage (Graham [1981] 2001, p. 55) and "radiance of drift and doubt" pointing to a person "who does not consider himself to be in the right" (Ziporyn 2009, p. 152). 
While Confucius' appeal to put the mind and knowledge on the "outside" (wai 外) is sometimes understood as the expression of Zhuangzi's "intuitionism" which exceeds the "regular function of human senses" (Liu 2015, p. 216), the reference to senses here is still apparent. The eyes (and ears) are to be directed inwardly (nei 内), possibly to detect the "empty chamber" ( $x u$ shi 虛室) that is told to emit "brightness" (bai 白). This "brightness" appears to emerge only under certain circumstances and in a specific environment (as communicated through the enigmatic notion of "closed room" (que 関)), which is a possible hint to certain techniques (associated with emptiness). ${ }^{29}$

In most other instances, vision is discussed as a "perspective" from which we see the world. In a sense, we can even say with Ziporyn that a "thing" in Zhuangzi's philosophy is a "perspective" (Ziporyn 2012, p. 172). However, any perspective can provide us only partial, limited access to reality. The inevitable consequence of such partial standpoints encountering each other is conflict and strife as exemplified by the debates between Confucians and Mohists, of whom Zhuangzi thinks "as lighting up little areas of life and leaving the rest in darkness" (Graham [1981] 2001, p. 53). Zhuangzi's solution to this controversy is also coined in terms of light metaphors and is called "illuminating things in the light of Heaven" (zhao zhi yu tian 照之于天) and "using clarity" (yi ming 以明) as follows from the below passage:

因是因非，因非因是。是以聖人不由，而照之于天，亦因是也。是亦彼也，彼亦是也。 $\ldots$ 彼是莫得其偶, 謂之道樞。樞始得其環中, 以應無窮。是亦一無窮, 非亦一無窮也。故日 「莫若以明」。(Zhuangzi 2/4/14-20)

"This" and "that" are mutually dependent; right and wrong are also mutually dependent. Therefore, the sage does not proceed in such a way but illuminates all in the light of Heaven. And that too is only a case of going by the rightness of the present "this." "This" is also a "that." "That" is also a "this." [ ... ] A state in which "this" and "that" no longer find their opposites is called the hinge of the Way. When the hinge is fitted into the socket, it can respond endlessly. For it has an endless supply of "rights," and an endless supply of "wrongs." So I say, the best thing to use is clarity.

(Here, I combine translations by Watson [1968] 2013 (2013, p. 10), Mair (1994, p. 15) and Ziporyn (2009, pp. 70-72).)

While seemingly solely criticizing the limitations and rigidity of Confucians and Mohists, this passage rather addresses the inevitable restrictions of any particular "view". The "hinge of the Way" (dao shu道 樞)—another metaphor for how the problem of partiality and bias is to be solved—is usually associated with the central position in a circle which is equally removed from the periphery representing opposing views and conflicting opinions. When observed from this centre, "this" and "that" no longer stand in opposition to each other. Returning to the imagery of vision and light, we see that "using clarity" and "illuminating things in the light of Heaven" expands the initially limited area of what one can "see".

This process has been, perhaps more than any other among the Zhuangzi's precepts, subject to radically different interpretations, ranging from penetrating the underlying unity of things (Radice 2001, p. 39) to merely realizing and accepting the obvious "surface" fact that different perspectives "affirm themselves and negate each other" (Ziporyn 2012, p. 175). Without attempting to resolve this complex issue, I would like to focus instead on the question of the source of light allowing the sage to see things in an all-inclusive perspective. The mentioning of "Heaven" (tian 天) appears to suggest that the "locus of illumination lies [not in the sage but] in Heaven" (Lo 1999, pp. 165-66). However, Heaven as promulgated in the Zhuangzi is seldom to be distinguished from man. ${ }^{30}$ Likewise,

29 In addition to "fasting of the mind" (xinzhai 心齋), the Zhuangzi also promulgates the techniques of "sitting and forgetting" (zuowang 坐忘) and “seeing the loneness" (jiandu 見獨). For more, see Liu (2015, pp. 204-6).

30 However, we can distinguish a "positive" and a "negative" view on the connection between man and Heaven. The "positive" view states that: "Heaven is not something distinct from earth and man, but a name applied to the natural and spontaneous 
in the above passage, the "clarity" and "illumination in light of Heaven" describe a state of the human psyche when the "rights" and "wrongs" do not find their "oppositions" (ou 偶). As we will see below, having no "opposition" leads to the loss of the "self". So strictly speaking, "clarity" and the "light of Heaven" cannot be attributed to a concrete person with a particular set of "rights" and "wrongs" but is necessarily experienced as impersonal. ${ }^{31}$

"Using clarity" gives the sage a great degree of flexibility when confronted with the rigid perspectives of other people as well as understanding how to deal with them in the best possible way. The best example of this flexible attitude is given in the story about the monkey keeper who reacted to the monkeys' initial discontent about the prospect of receiving three chestnuts in the morning and four in the evening by simply swapping the number of chestnuts given to them in the morning and in the evening thus making them delighted. Concluding this story, the Zhuangzi says:

\section{名實未虧，而喜怒為用，亦因是也。是以聖人和之以是非，而休乎天鈞，是之謂兩行。 (Zhuangzi 2/5/5-6)}

There was no change in the reality behind the words and yet the monkeys responded with joy and anger. This is also an example of following "this". So the sage harmonizes the right and wrong of things and rests at the centre of the potter's wheel of Heaven. This is called walking two roads. (See Watson [1968] 2013, p. 11; Mair 1994, p. 17)

Accordingly, the sage, resting in the centre of the "potter's wheel of Heaven" (tian jun 天鈞)—yet another metaphor for the exemplary being's detachment from common value judgments (for more, see De Reu 2010)—is able to "harmonize" (he 和) with others" "right" and "wrong" by adapting his actions to a concrete situation. In the case of the monkey keeper, his actions seemed to be determined by "the prospect of conflict" and the attempt to "diffuse" it (De Reu 2010, pp. 52-53). Hence, it stands to reason that "using clarity" and "illuminating things in light of Heaven" includes profound knowledge of different life situations and appropriate strategies for dealing with them in a harmonious manner. In other words, sages know how "to change their practice to fit different contexts in ordinary life" (Lai and Wai 2013, p. 537). The harmony that the sage thus achieves concerns his everyday interactions and is ultimately based on his understanding of the complex interrelation between the different perspectives (Ziporyn 2003, p. 53).

\subsection{Auditory Metaphors}

The "fasting of the heart" suggested to Yan Hui by Confucius puts a strong emphasis on the importance of "listening" (ting 聽), as seen below:

仲尼日：「若一志, 聽之以耳而聽之以心, 聽之以心而聽之以氣。聽止於耳, 心止於符。氣 也者，虛而待物者也。唯道集虛。虛者，心齋也。」顔回日：「回之未始得使，實自回也； 得使之也，未始有回也。可謂虛乎?」夫子曰：「盡矣。」(Zhuangzi 4/10/1-4)

Confucius said: “Make your will one! Don't listen with your ears, listen with your heart. No, don't listen with your heart, but listen with your qi. Listening stops with the ears, the heart stops with recognition, but $q i$ is empty and waits for all things. The Way gathers in emptiness alone. Emptiness is the fasting of the heart." Yan Hui said, "Before I heard this, I was certain that I was Hui. But now that I have heard it, there is no more Hui. Can this be called emptiness?" "That's all there is to it," said Confucius. (Watson [1968] 2013, p. 25)

functioning of the two" (Watson [1968] 2013, p. 8). The "negative" standpoint promulgates the idea that: "Heaven [ ... ] is not the secret hidden essence of things, the harmonious creator behind their present conflicting appearances, but rather that surface of obvious conflict itself, once we cease the futile attempt to try to get to the bottom of it or find out what harmony lies behind it" (Ziporyn 2012, p. 175).

31 This is reminiscent of Robert Allison's view that the concept of harmony with the Way cannot emerge during the experience of the Way "because there are no distinctions to be harmonized during that state" (Allison 1988, p. 182). Accordingly, such a concept can emerge only either prior to or after this realization. 
Accordingly, Confucius distinguishes between the three different levels with which a person engage in the physical act of listening: using the "ears" (er 耳), “heart" ( $x$ in 心) and $q i$ 氣. ${ }^{32}$ Among them, only the former denotes auditory perception in the generic sense, while "listening with $q i$ " is often explained in terms of meditative practices of focusing on one's "breathing" (Roth 1999, p. 155). ${ }^{33}$ In the current investigation, however, it is the appearance of "listening" in connection with "emptiness" ( $x u$ 虛), “heart" and the attitude of "waiting" (dai 待) that is especially worth noticing. With Sweetser it could be explained as follows: "auditory 'channelling' is mainly a mental activity", therefore "it is natural that auditory reception should be linked with heedfulness and internal 'receptivity'" (Sweetser 1990, p. 41). Now, the "emptiness" of the heart can certainly have different interpretations ${ }^{34}$ but here it seems to signal the utmost heedfulness of the discerning subject up to the point of losing his self: “there is no more Hui” (未始有回也).

The second example of auditory metaphors is "hearing", which frequently appears in the following conversation between Nanbo Zikui and Woman Crookback from chapter six, "The Great and Venerable Teacher" (Dazongshi 大宗師):

\section{南伯子葵問乎女偶日：「子之年長矣，而色若孺子，何也？」日：「吾聞道矣。」.. 南伯 子葵曰：「子獨惡乎聞之? 」曰：「聞諸副墨之子，副墨之子聞諸洛誦之孫，洛誦之孫聞之

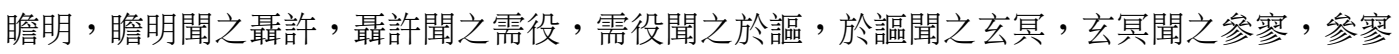 聞之疑始。」(Zhuangzi 6/17/10-20)}

Nanpo Zikui said to the Woman Crookback, "You are old in years, and yet your complexion is that of a child. Why is this?"

"I have heard the Way!" [ . . ] Nanpo Zikui asked, "Where did you happen to hear this?" "I heard it from the son of Aided-by-Ink, and Aided-by-Ink heard it from the grandson of Repeated-Recitation, and the grandson of Repeated-Recitation heard it from Seeing-Brightly, and Seeing-Brightly heard it from Whispered-Agreement, and Whispered-Agreement heard it from Waiting-for-Use, and Waiting-for-Use heard it from Exclaimed-Wonder, and Exclaimed-Wonder heard it from Dark-Obscurity, and Dark-Obscurity heard it from Participation-in-Mystery, and Participation-in-Mystery heard it from Copy-the-Source!" (Watson [1968] 2013, pp. 46-47)

From this passage, we can draw several implications in regard to the meaning of "hearing" in the Zhuangzi. On the one hand, this verb seems to signify a direct experience of the Way, which had such a profound impact on "Woman Crookback" as to change her appearance. On the other hand, however, the same term is used here to emphasize the importance of instruction as well as to construct the authority of a particular lineage which began with "Copy-the-Source" (Yishi 疑始) and, by means of oral transmission, eventually reached Woman Crookback. The blurred lines between the Way as the universal principle and the teaching of this particular lineage, aims to underscore the authority of the latter.

The last example of "hearing" to be discussed is in the "piping of Heaven" story which opens the second chapter, "Qiwulun", quoted in full length due to its importance:

南郭子綦隱几而坐，仰天而噓，嗒焉似喪其耦。顔成子游立侍乎前，日：「何居乎? 形固可 使如槁木, 而心固可使如死灰乎? 今之隱几者, 非昔之隱几者也。」子綦日：「偃, 不亦善

32 The Wenzi 文子 contains a very similar classification of listening but connects it to different types of learning. For more, see Van Els (2006, pp. 80-86, 98-103) and Fech (2018a, pp. 208-20).

33 For similar interpretations, see also (Graham [1981] 2001, p. 69) and Yang (2003, pp. 92-95).

34 Xunzi offers a complex definition of “emptiness” (21/104/2): 人生而有知, 知而有志; 志也者, 藏也; 然而有所謂虛 ; 不以 所已㶓害所將受謂之虛。(Cheuk and Ching 1996) “Men from birth have awareness. Having awareness, there is memory. Memories are what is stored, yet the mind has the property called emptiness. Not allowing what has previously been stored to interfere with what is being received in the mind is called emptiness" (Knoblock 1994, p. 104). 
乎而問之也! 今者吾喪我, 汝知之乎? 女聞人籟而未聞地籟, 女聞地籟而未聞天籟夫! 」子游 日：「敢問其方。」子綦日：「夫大塊噫氣, 其名為風。是唯作, 作則萬竅怒呺。而獨不 聞之翏翏乎? 山林之畏佳, 大木百圍之竅穴, 似鼻, 似口, 似耳, 似枅, 似圈, 似臼, 似洼 者, 似污者; 激者, 謞者, 叱者, 吸者, 叫者, 譹者, 审者, 咬者, 前者唱于而隨者唱喁。 泠風則小和, 飄風則大和, 庽風濟則衆竅為虛。而獨不見之調調、之习习乎? 」子游曰： 「地籟則衆憿是已, 人籟則比竹是已。敢問天籟。」子綦日：「夫吹萬不同, 而使其自己 也, 咸其自取, 怒者其誰邪! 」(Zhuangzi 2/11/14-24)

Ziqi of South Wall sat leaning on his armrest, staring up at the sky and breathing-vacant and far away, as though he'd lost his companion. Yan Cheng Ziyou, who was standing by his side in attendance, said, "What is this? Can you really make the body like a withered tree and the mind like dead ashes? The man leaning on the armrest now is not the one who leaned on it before!"

Ziqi said, "You do well to ask the question, Yan. Now I have lost myself. Do you understand that? You hear the piping of men, but you haven't heard the piping of earth.

Or if you've heard the piping of earth, you haven't heard the piping of Heaven!"

Ziyou, "May I venture to ask what this means?"

Ziqi said, "The Great Clod belches out breath, and its name is wind. So long as it doesn't come forth, nothing happens. But when it does, then ten thousand hollows begin crying wildly. Can't you hear them, long drawn out? In the mountain forests that lash and sway, there are huge trees a hundred spans around with hollows and openings like noses, like mouths, like ears, like jugs, like cups, like mortars, like rifts, like ruts. They roar like waves, whistle like arrows, screech, gasp, cry, wail, moan, and howl, those in the lead calling out yeee! those behind calling out yuuu! A light breeze brings a small harmony, while a powerful gale makes for a harmony vast and grand. And when the fierce wind has passed on, then all the hollows are empty again. Have you never seen the tossing and trembling that goes on?"

Ziyou said, "By the piping of earth, then, you mean simply [the sound of] these hollows, and by the piping of man, [the sound of] flutes and whistles. But may I ask about the piping of Heaven?" Ziqi said, "Blowing on the ten thousand things in a different way, so that each can be itself-all take what they want for themselves, but who does the sounding?"

(Adapted from Watson [1968] 2013, pp. 7-8; Ziporyn 2009, p. 9)

First, it is noteworthy that the protagonist "Ziqi of Southwall" reported to his student to have lost his "self" (wo 我), while, at the same time, having the outer appearance of someone who has lost his "companion" or "counterpart" (ou 耦). Regardless of what the "self", "counterpart" and the process of their "loss" (sang 喪) exactly stand for ${ }^{35}$, what is described here is reminiscent of the "hinge of the Way" where "this" and "that" lose their oppositions. It is in light of this parallel, that various sounds produced by the hollows of the trees are taken to mean "conflicting utterances of philosophers" (Graham [1981] 2001, p. 49) and, on a larger scale, to also include "emotional perspectives", "concepts of identity" as well as "life" and "death" (Ziporyn 2003, p. 35). However, the "piping of Heaven" has its unique significance in that it is a musical metaphor. As such, it first reflects the common pre-Qin belief that "great music stems from the cosmic processes of Heaven and Earth" and that whoever "can preserve the original imprint of Heaven's pattern on his heart-mind will be able to understand such music" (Brindley 2012, pp. 115-16). Secondly, as music, that is, "a perfect combination of diverse pairs of opposing elements" (Jo 2017, p. 378), the "piping of Heaven" entails a notion of "harmony" (he 和) which is opposed to "sameness" (tong 同). It is certainly questionable whether we can infer

35 For a detailed study of this question including an overview of the most characteristic positions, see Ming (2016). 
from this that Ziqi of Southwall actually appreciated the different sounds (that is, conflicting theories) he was hearing, given their consequent criticism in the inner chapters. But, because the recognition of harmony has to do with the "attitude of the listener" (Cook 2003, p. 75), Ziqi of Southwall appears here not as a "perceptual" but an "aesthetic" virtuoso. That is, he differs from his puzzled disciple not in the what but in the how of his auditory perception. Lastly, in order to be able to hear and understand a piece of music one has to be silent. The empty and silent state is evident in Ziqi's loss of the self and him looking like "a withered tree". As we saw above, it is this impersonal state that the Zhuangzi calls "Heaven" and not a certain separate entity. The centrality of the wind in the story that, while being "something invisible, the power of a no-thing", produces music by blowing on the cavities which are themselves "a lack" (Wu 1990, p. 186) seems to underscore this point. ${ }^{36}$

\section{3. "Grasping" Metaphors}

In contrast to the Laozi, which frequently addresses the relation between man and the Way in terms of "grasping", there are almost no such metaphors of control in the inner chapters of the Zhuangzi. And in the occasional mentions of "grasping" ( $z h i$ 執), its object is never the Way or Heaven. ${ }^{37}$ I believe this has something to do with the fact that, even in the stories involving vision and light, the Zhuangzi praises as ideal the impersonal state in which the distinction between "this" and "that", including "man" and "Heaven", is not existent. Therefore, the grasper and the grasped are not present in this experience. Moreover, the Zhuangzi's characteristic attitude towards the great use of uselessness, highlighted specifically in the inner chapters, could explain why his highest principles never appear in the context of utility. ${ }^{38}$ Thus, it is possibly for these reasons the Zhuangzi prefers to use metaphors of "unity" or "wandering" when talking about the highest realization. ${ }^{39}$

\subsection{Visual and Auditory Metaphors in the Context of the Zhuangzi's Philosophy}

When summarizing the instances of visual and auditory metaphors in the Zhuangzi, we see that, just like in the Laozi, they emphasize different aspects of human life and cognition. While the visual metaphors are connected with a more proactive stance in life, requiring one to take certain actions to achieve harmony in social interaction, "hearing", while at times indicating transmission of authoritative knowledge, puts a greater emphasis on the inner dimension of the process in which a subject loses his self as a result of utter emptiness and heedfulness. That is to say, "illuminating things in the light of Heaven" appears to suggest a (limitless) extension of one's focus to include an infinite number of possible perspectives, whereas hearing the "pipes of Heaven" seems to be a matter of the inner attitude with which perceived contents are processed. Nevertheless, in both cases, the Zhuangzi stresses dramatic shifts in the original perspective of the cognizing subject. According to some scholars, this ensuing impersonal state of acute vision and hearing is at the heart of the Zhuangzi's notion of "authenticity" (zhen 真), which "implies a natural state of responsiveness where the person acts efficaciously by being in line with what is obvious or affirmed in the situation" (Moeller and D’Ambrosio 2017, p. 353).

36 As Ziporyn puts it, "it is thus perhaps this question itself-the "who?" [that concludes the "piping of Heaven" story]—that most adequately evokes the wonder of the unfixable multifariousness of the wind's sonic identity" (Ziporyn 2012, p. 166).

37 Duke Ai of Lu魯哀公 is said in chapter five, “The Sign of Virtue Complete” (de chong fu 德充符), to “grasp the 'reins' of (governing) the people" (zhi min zhi ji 執民之紀) (for the whole passage, see Mair 1994, pp. 46-48).

38 For the use of usefulness in the Zhuangzi, see Galvany (2009). The monkey keeper from chapter two exhibiting a flexible attitude puts to use the monkeys' "joy and anger" ( $x i$ nu 喜怒).

39 For unity, see Zhuangzi 6/19/21: 同於大通。“to become identical with the Great Thoroughfare.” For unity and wandering, see Zhuangzi 6/18/20-21: 假於異物, 託於同體, 忘其肝膽, 遺其耳目, 反覆終始, 不知端倪, 芒然彷徨乎塵垢之外, 逍遙 乎無為之業。“They borrow the forms of different creatures and house them in the same body. They forget liver and gall, cast aside ears and eyes, turning and revolving, ending and beginning again, unaware of where they start or finish. Idly they roam beyond the dust and dirt; they wander free and easy in the service of inaction" (Watson [1968] 2013, p. 50). 


\section{Conclusions}

By way of conclusion, we can say that the meaning of vision and hearing in the two major Daoist works is determined by their view of reality and the place humans occupy in it. This is why their differences are greater than their similarities, such as references to "inward vision". As a "dark" reality, the Way of Laozi has to be illuminated to be understood. To offset the sage's control over the Way by means of illumination and grasping, the text places him into the obeying position of a "listener", determining the Way as the paradigm of "authenticity". Thus, only an "authentic" person can be in the position to make claims to truth (and, given the Laozi's political preoccupation, to power). In the Zhuangzi, on the other hand, the ideal human illuminates different views and opinions of his contemporaries, rather than the mysterious origin of the world. Therefore, the problem of the sage establishing his authority over the text's main principle does not emerge here. Especially when considered that, in the Zhuangzi, the highest reality is associated with a state of human psyche which has been cleansed of any associations with a particular emotional or intellectual perspective as well as a sense of identity. ${ }^{40}$ The hearing, providing, by virtue of its physiological characteristics, connection to the inner attitude and heedfulness, serves Zhuangzi as a particularly good tool for conveying his idea of "authenticity".

Funding: This research received no external funding.

Conflicts of Interest: The authors declare no conflict of interest.

\section{References}

Allison, Robert E. 1988. The Concept of Harmony in Chuang Tzu. In Harmony and Strife. Contemporary Perspectives, East $\mathcal{E}$ West. Edited by Shu-hsien Liu and Robert Allison. Hong Kong: The Chinese University Press, pp. 169-86.

Behunaik, James, Jr. 2009. “Embracing the One" in the Daodejing. Philosophy East and West 59: 364-81.

Beida-Laozi: Beijing daxue chutu wenxian yanjiusuo 北京大學出土文獻研究所 [The institute for research of the excavated documents of the Peking University]. 2012. Beijing daxue cang Xi-Han zhushu 北京大學藏西漢竹書 (Vol. 2). Shanghai: Shanghai Guji Chubanshe.

Blumenberg, Hans. 1993. Light as a Metaphor for Truth: At the Preliminary Stage of Philosophical Concept Formation. In Modernity and the Hegemony of Vision. Edited by David Michael Levin. Berkeley, Los Angeles and London: University of California Press, pp. 30-62. First published 1957.

Brindley, Erica Fox. 2012. Music, Cosmology and the Politics of Harmony in Early China. Albany: State University of New York Press.

Brown, Miranda, and Uffe Bergeton. 2008. 'Seeing' Like a Sage: Three Takes on Identity and Perception in Early China. Journal of Chinese Philosophy 35: 641-62. [CrossRef]

Chan, Alan K. 1991. Two Visions of the Way: A Study of the Wang Pi and the Ho-Shang Kung Commentaries on the Lao-Tzu. Albany: State University of New York Press.

Chan, Alan K. 2014. The Art of Hearing and the Promise of Harmony in Confucian Self-Cultivation. In New Directions in Chinese Philosophy. Edited by Chung-yi Cheng. Hong Kong: The Chinese University Press, pp. 103-15.

Chan, Wai Keung. 2010. Jade Flower and the Motif of Mystic Excursion in Early Religious Daoist Poetry. In Interpretation and Literature in Early Medieval China. Edited by Alan K. L. Chan and Lo Yuet-Keung. Albany: State University of New York Press.

Chan, Wing-Tsit. 1963. A Source Book in Chinese Philosophy. Princeton: Princeton University Press.

Cook, Scott. 2003. Harmony and Cacophony in the Panpipes of Heaven. In Hiding the World in the World: Uneven Discourses on the Zhuangzi. Edited by Scott Cook. Albany: State University of New York, pp. 64-87.

40 Note that, unlike the Laozi, the Zhuangzi does not use possessive pronouns, such as, for instance, "his" ( $q$ 其) when speaking about the light used by the sage. 
De Reu, Wim. 2010. How to Throw a Pot: The Centrality of the Potter's Wheel in the Zhuangzi. Asian Philosophy: An International Journal of the Philosophical Traditions of the East 20: 43-66. [CrossRef]

Erkes, Eduard. 1945. Ho-Shang-Kung's Commentary on Lao-tse. Artibus Asia 8: 119-96. [CrossRef]

Fech, Andrej. 2018a. Auditory Perception and Cultivation: the Wenzi. In Cultivating a Good Life in Early Chinese and Ancient Greek Philosophy. Edited by Karyn Lai, Rick Benitez and Hyun Jin Kim. London, New York, Oxford, New Delhi and Sydney: Bloomsbury Academic, pp. 208-20.

Fech, Andrej. 2018b. Reflections on Artisan Metaphors in the Laozi: Who Cuts the 'Uncarved Wood' ( $p u$ 樸)? (Parts 1 and 2). Philosophy Compass 13: 1-10 and 1-11.

Gadamer, Hans-Georg. 1998. Truth and Method. London, New York, Oxford, New Delhi and Sydney: Bloomsbury Academic. First published 1960.

Galvany, Albert. 2009. Discussing Usefulness: Trees as Metaphor in the Zhuangzi. Monumenta Serica 57: 71-97. [CrossRef]

Gao, Ming 高明. 1996. Boshu Laozi jiaozhu 帛書老子校注. Beijing: Zhonghua.

Geaney, Jane. 2011. The Sounds of Zhengming: Setting Names Straight in Early Chinese Texts. In Ethics in Early China. Edited by Chris Fraser. Hong Kong: Hong Kong University Press, pp. 125-41.

Graham, Angus. 2001. Chuang-tzu: The Seven Inner Chapters and Other Writings from the Book Chuang-tzu. Indianapolis and Cambridge: Hackett Publishing Company. First published 1981.

Henricks, Robert G. 2000. Lao Tzu's Tao Te Ching: A Translation of the Startling New Documents Found at Guodian. New York: Columbia University Press.

Jo, Jungjeon. 2017. Musical Harmony in the Xunzi and the Lushi Chunqiu: Different Implications of Musical Harmony Resulting from Their Dissimilar Approaches to the Concept of Resonance between Sound and Qi. Dao 16: 371-87. [CrossRef]

Johnston, Ian, and Ping Wang. 2012. Daxue and Zhongyong: Bilingual Edition. Hong Kong: The Chinese University of Hong Kong.

Klein, Esther. 2010. Were there "Inner Chapters" in the Warring States? A New Examination of Evidence about the Zhuangzi. T'oung Pao 96: 299-369. [CrossRef]

Knoblock, John. 1994. Xunzi: A Translation and Study of the Complete Works. Stanford: Stanford University Press, vol. III.

Kohn, Livia. 1998. Mind and Eyes: Sensory and Spiritual Experience in Daoist Mysticism. Monumenta Serica 46: 129-56. [CrossRef]

Lai, Karyn, and Wai Chiu Wai. 2013. Ming in the Zhuangzi Neipian: Enlightened Engagement. Journal of Chinese Philosophy 40: 527-43. [CrossRef]

Lakoff, George, and Mark Johnson. 1999. Philosophy in the Flesh: The Embodied Mind and Its Challenge to Western Thought. New York: Basic Books.

A Concordance to the Laozi (Laozi zhuzi suoyin 老子逐字索引). 1996. Cheuk, Lau Dim, and Chen Fong Ching, eds. Hong Kong: Commercial Press.

Lau, Dim Cheuk 劉殿爵 (Liu Dianjue). 2001. Tao Te Ching. Hong Kong: The Chinese University Press.

Liu, Xiaogan. 1988. Zhuangzi zhexue ji qi yanbian 莊子哲學及其演變. Beijing: Zhongguo Shehui Kexue Chubanshe.

Liu, Xiaogan. 1999. The Core Value of Laozi's Philosophy. In Religious and Philosophical Aspects of the Laozi. Edited by Philip J. Ivanhoe and Mark Csikszentmihalyi. Albany: State University of New York Press, pp. 211-38.

Liu, Xiaogan, ed. 2015. Zhuangzi's Philosophy: A Three Dimensional Reconstruction [Chapter 8]. In Dao Companion to Daoist Philosophy. Dordrecht, Heidelberg, New York and London: Springer, pp. 193-219.

Lo, Yuet Keung 勞悦强 (Lao Yueqiang). 1999. The Idea of Ming in the Zhuangzi. Monumenta Serica 47: 149-68. [CrossRef]

Mair, Victor H. 1994. Wandering of the Way: Early Taoist Tales and Parables of Chuang Tzu. New York: Bantam Books.

Ming, Thomas. 2016. Who Does the Sounding? The Metaphysics of the First-Person Pronoun in the Zhuangzi. Dao 15: 57-79. [CrossRef]

Moeller, Hans-Georg, and Paul J. D'Ambrosio. 2017. Genuine Pretending: on the Philosophy of the Zhuangzi. New York: Columbia University Press.

Møllgaard, Eske. 2007. An Introduction to Daoist Thought: Action, Language, and Ethics in Zhuangzi. London and New York: Routledge.

Radice, Thomas. 2001. Clarity and Survival in the Zhuangzi. Asian Philosophy: An International Journal of the Philosophical Traditions of the East 11: 33-740. [CrossRef] 
Roth, Harold David. 1999. Original Tao: Inward Training (Nei-yeh) and the Foundations of Taoist Mysticism. New York: Columbia University Press.

Sharma, Pallavi, and Archana Barua. 2017. Analysing Gaze in Terms of Subjective and Objective Interpretation: Sartre and Lacan. Human Studies 40: 61-75. [CrossRef]

Slingerland, Edward. 2003. Effortless Action: Wu-wei As Conceptual Metaphor and Spiritual Ideal in Early China. Oxford: Oxford University Press.

Sweetser, Eve. 1990. From Etymology to Pragmatics: Metaphorical and Cultural Aspects of Semantic Structure. Cambridge: Cambridge University Press.

Van Els, Paul. 2006. The Wenzi: Creation and Manipulation of a Chinese Philosophical Text. Ph.D. thesis, Leiden University, Leiden, The Netherlands.

Wagner, Rudolf G. 2003. A Chinese Reading of the Daodejing, Wang Bi's Commentary on the Laozi with Critical Text and Translation. Albany: State University of New York.

Waley, Arthur. 1994. The Way and Its Power. London: George Allen \& Unwin LTD. First published 1934.

Wang, Shumin 王叔岷. 1988. Zhuangzi jiaoquan 莊子校詮, shang ce 上冊. Taibei: Zhongyang yanjieyuan lishi yuyan yanjiusuo.

Watson, Burton. 2013. The Complete Works of Zhuangzi. New York: Columbia University Press. First published 1968.

Wu, Kuang-ming. 1990. The Butterfly as Companion: Meditations on the First Three Chapters of the Chuang Tzu. Albany: SUNY Press.

A Concordance to the Xunzi (Xunzi zhuzi suoyin 荀子逐字索引). 1996. Cheuk, Lau Dim, and Chen Fong Ching, eds. Hong Kong: Commercial Press.

Yang, Rur-Bin 楊儒賓 (Yang Rubin). 2003. From “Merging the Body with the Mind" to “Wandering in Unitary Qi 氣": A Discussion of Zhuangzi's Realm of the True Man and Its Corporeal Basis. In Hiding the World in the World: Uneven Discourses on the Zhuangzi. Edited by Scott Cook. Albany: State University of New York, pp. 88-127.

A Concordance to the Zhuangzi (Zhuangzi zhuzi suoyin 莊子逐字索引). 2000. Cheuk, Lau Dim, Ho Che Wah, and Chen Fong Ching, eds. Hong Kong: Commercial Press.

Ziporyn, Brook. 2003. How Many are the Ten Thousand Things and I? Relativism, Mysticism, and the Privileging of Oneness in the "Inner Chapters". In Hiding the World in the World: Uneven Discourses on the Zhuangzi. Edited by Scott Cook. Albany: State University of New York, pp. 33-63.

Ziporyn, Brook. 2009. Zhuangzi: The Essential Writings: With Selections from Traditional Commentaries. Indianapolis and Cambridge: Hackett Publishing Company.

Ziporyn, Brook. 2012. Ironies of Oneness and Difference-Coherence in Early Chinese Thought, Prolegomena to the Study of Li. Albany: State University of New York Press. 